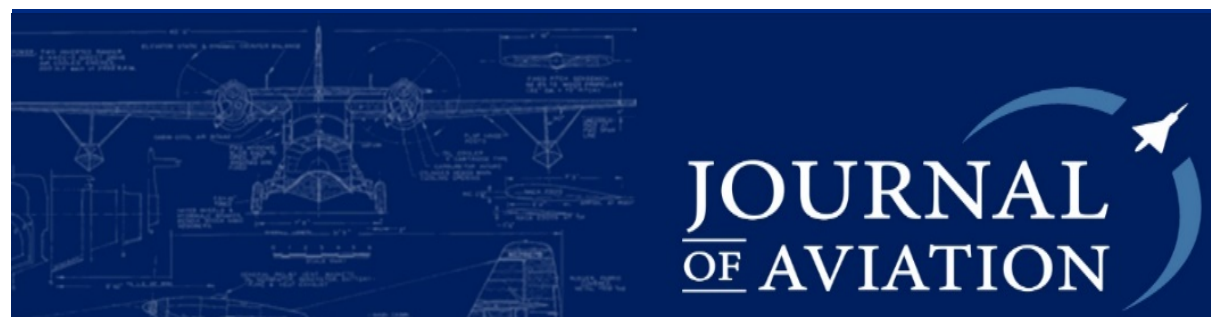

e-ISSN: 2587-1676

Araştırma Makalesi/Research Article

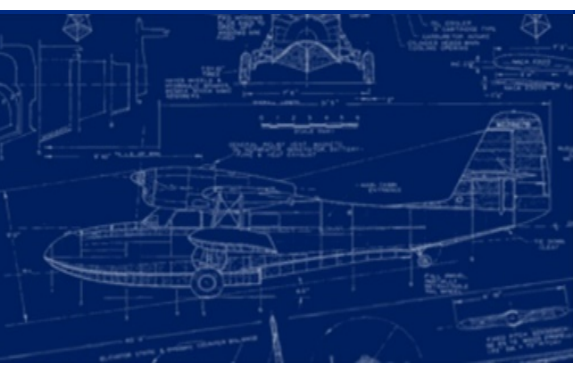

J Aviat 2020; 4(1): 126-146

DOI : $10.30518 /$ jav.731513

\title{
Hava Yolu İşletmelerinde Uçuş Güvenliği Uygulamaları \\ ve İyileştirme Önerileri
}

\author{
M.Melih BAŞDEMIR ${ }^{1 *(\mathbb{D})}$
}

Türk Hava Yolları, Uçuş İşletme Başkanlığı, İstanbul, Türkiye

\begin{abstract}
Özet
Uçuş operasyonlarının en önemli amacı uçuşları etkin ve emniyetli bir şekilde yerine getirmektir. Uçuş etkinliğini ve emniyetini yerine getirebilmek için güvenlik ve emniyeti kavramları her zaman önemli bir rol oynamaktadırlar. Havacılık endüstrisi için her zaman var olması gereken bu iki kavramdan uçuş güvenliği; uçuşun başlangıcından sonuna kadar uçuşu terör, saldırı, müdahale, vb. her türlü tehdide karşı korumak, uçuş emniyeti ise uçuş boyunca uçuş sistemleri ve uçuşun yapıldığı ortamlarda belirlenmiş kurallara uygun olarak uçulmasını sağlamaktır. $\mathrm{Bu}$ araştırmada uçuş güvenliği incelenmiş ve hava yolu şirketlerinde uçuşların daha güvenli bir şekilde yerine getirilebilmesi için yapılması gerekenler belirlenmiştir. Araştırma kapsamında nitel araştırma yöntemi tekniklerinden arşiv taraması ile veri toplanmış ve daha sonra elde edilen bulgular doğrultusunda hava yolu çalışanlarının güvenlik dokümanlarına ithal edilmek ve kurumsal düzeyde uçuş güvenliğini arttırmak amacıyla bir öneri seti hazırlanmıştır. Bu kapsamda, öncelikle ICAO ve havayolu şirketleri tarafından kullanılan uçuş güvenliğine ilişkin kural ve yönetmelikler incelenmiş, sonrasında ise 2001-2017 yılları arasında meydana gelmiş olan uçuş güvenliğini zedeleyici terör eylemleri taranarak içerik analizleri yapılmıştır. $\mathrm{Bu}$ inceleme ve analizlerin sonrasında ise yapılması gerekenler anlatılmıştır. Bu çalışmadaki ana amaç 'hava yolu şirketlerinde uçuş güvenliği daha etkin bir şekilde nasıl sağlanır' sorusuna bir öneri seti ile cevap aramaktır. Çalışmanın hava yolu işletmelerindeki uçuş güvenliği uygulamalarına yeni bir bakış açısı kazandıracağı değerlendirilmektedir.
\end{abstract}

Anahtar Kelimeler: Hava Yolu İşletmeleri, Uçuş Güvenliği, Uçuş Emniyeti, Terörizm, Uçuş Operasyonları.

Corresponding Author/SorumluYazar: Dr. Kaptan ve Öğretmen Pilot, M.Melih Başdemir, mbasdemir@thy.com Citation/Alıntı: Melih M. Başdemir, (2020). Hava Yolu İşletmelerinde Uçuş Güvenliği Uygulamaları ve İyileştirme Önerileri J. Aviat. 4 (1), 126-146.

ORCID: ${ }^{1}$ https://orcid.org/0000-0001-8380-2700

DOI: https://doi.org/10.30518/jav.731513

Gelis/Received: 3 Mayıs 2020 Kabul/Accepted: 21 Haziran 2020 Yayınlanma/Published (Online): 23 Haziran 2020

Copyright@ 2020 Journal of Aviation https://javsci.com - http://dergipark.gov.tr/jav 


\title{
Flight Security Applications in The Airline Companies and
}

\author{
Practical Recommendations
}

\begin{abstract}
Flight Operations' sole objective is to ensure effective and safe flights. In order to fulfill this objective, flight safety and security should be enhanced by all means. Flight security, which is an indispensible concept of the aviation industry along with its brother term of flight safety, means to protect the flights from all kinds of threats, such as terrorist attacks, assaults and intrusions, while flight safety is to ensure flights to be conducted in accordance with rules and procedures. In this paper, flight securtiy is investigated, and things to be done for more secure flights are found out. For the sake of the research, a qualitive method based on archivical data gathering technic is used. Findings after the data analysis are used to form a set of security improvement recommendations for the airline companies. Within this scope, initially, flight security procedures outlined by ICAO and implemented by the airline companies are investigated, then terrorist attacks occured between 2001-2017 are thoroughly secreened whereby a content analysis is conducted. After these analyses and investigations, things to be done to improve the flight security is listed. The primary objective of this research is to seek an answer to the question of "how can the airline companies improve the flight security within the flight operations" with the help of a practical recommendations set. It is hoped that this study will augment a new perspective to the context of flight security.
\end{abstract}

Key Words: Airline Companies, Flight security, Flight Safety, Terrorism, Flight Operations.

\section{Giriş}

Havacılık Endüstrisi, bilindiği gibi sürekli bir gelişim halindedir. Ekonomik olarak karlı olma amacını güden havayolu şirketleri, aynı zamanda emniyetli ve güvenli uçuş operasyonları yapmak zorundadırlar. Şirketlerin güvenlik ve emniyet bakımlarından kusursuz olmaları doğrudan şirketlerin ekonomik zenginliklerini etkilemektedir. $\mathrm{Bu}$ sebepten dolayı şirketlerin güvenlik ve emniyet politikalarının incelenmesi ve havacillk endüstrisinin daha güvenli bir şekilde faaliyet göstermesi için yapılması gerekenlerin aranmasının önemli olduğu düşünülmektedir.

Uçuş operasyonlarında sürekli olarak karıştırılan iki kavram bulunmaktadır: Emniyet ve Güvenlik. Uçuş emniyeti bir uçuşun bir noktadan diğerine herhangi bir kaza ya da olayla karşılaşmadan, can ve mal kayb1 yaşanmadan yerine getirilmesini ifade eder [1]. Uçuş güvenliği ise taşınan kargo ve yolcunun herhangi bir zarar görmeden, fiziki, siber ve diğer her türlü tehditten korunmuş bir şekilde uçuşun yerine getirilmesini anlatır [2].

Güvenlik kavramı hava yolu şirketlerinde ulusal ve uluslararası mevzuat gereği standartlara bağlanmıştır. $\mathrm{Bu}$ kapsamda, Uluslararası Sivil Havacılık Kuruluşu- International Civil Aviation Organization (ICAO) tarafından oluşturulmuş ICAO SARP (Standards and Recommended Practices) Annex 17 "Security” dokümanı en önemli dokümandır [3]. Türkiye'nin Avrupa Havacilık Emniyet Ajans1- European Aviation Safety Agency (EASA)'ya uyum sürecinde dikkate aldığ dokümanlar içinde $\mathrm{AB}$ Komisyonu'nun Uçuş Güvenliği konusunda Regulation EC No 300-2008 da [4] önem taşımaktadır. Ulusal mevzuatta da SHT (Sivil Havacılık Talimatı)-17- Havacılık İşletmeleri Güvenlik Yönetmeliği ve Organizasyonu [5] ile sivil havacilık güvenliğini, uluslararası standartlar ve kurallar çerçevesinde sağlamak amacıyla hazırlanıp, 24 Aralık 1996 tarihinde İçişleri ve Ulaştırma, Denizcilik ve Haberleşme Bakanlığı tarafından imzalanarak yürürlüğe giren Milli Sivil Havacılık Güvenlik Programı (MSHGP) bulunmaktadır [6]. Hava yolu şirketleri de bu mevzuat doğrultusunda pilotlara yönelik olarak Operational Manual Part A, kabin ekibine yönelik Cabin Crew Manual (CCM) ve yer personeline yönelik Ground Operation Manual (GOM) dokümanlarında uçuş güvenliği ile ilgili bölümleri bulundurmak zorundadırlar. Hava yolu şirketlerinin güvenlik uygulamaları bu çerçevede şekillenmektedir.

Uçuş operasyonlarındaki güvenlik konusu bu çalışmada "nitel analiz" yöntemi kullanılarak araştırılmaya çalışılmıştır. Nitel yöntem kapsamında ihtiyaç duyulan veriler "güvenlik açıkları ve terör eylemleri" hakkında kapsamlı bir "arşiv taraması" ile elde edilmeye çalışılmıştır. Bu 
şekilde elde edilen veriler, uçuculuk mesleğinin içinde olmanın verdiği "gözlemleme ve prosedürleri uygulama" avantaj1 sayesinde yorumlanmaya çalışılmıştır. Arşiv taraması yapılırken aynı zamanda havacılık güvenliği mevzuatı ve örnek terör olayları konusunda da derin bir şekilde ilgili literatür incelenmiştir. $\mathrm{Bu}$ incelemeler sonrasında elde edilen verilerle güvenlik uygulamalarına yönelik bir içerik analizi yapılmış ve saptanan bulguların bie "havacı gözüyle" yorumlanmasından sonra hava yolu şirketlerindeki uçuş güvenliğinin iyileştirilmesine ilişkin bir öneri seti hazırlamaya çalışılmıştır.

Araştırmanın alanı olarak hava yolu işletmeleri belirlenmiş, çalışmanın öncelikle tanımlayıcı (descriptive) olması ve bu tanımlamalar ve tespitler sonrasında hava yolu işletmelerinin güvenlik dokümanlarına yönelik önerilerin sunulması hedeflenmiştir. $\mathrm{Bu}$ kapsamda, öncelikle uçuş güvenliği konusunun uygulayıcı konumda olan havacılık şirketleri, havaalanı güvenlik birimleri, pilot ve kabin memurları tarafindan mevcut mevzuat doğrultusunda nasıl yapıldığı anlaşılmaya çalışılmıştır. $\mathrm{Bu}$ süreçte ağırlık, mevcut uçuş güvenliği dokümanlarını taranmasına ve güvenlik zafiyeti sonrasında meydana gelen "terör olaylarına" verilmiştir. Böylelikle, uçuş güvenliğinin tam olarak algılandığı ve olayların doğal ortamda gerçekçi ve bütüncül bir biçimde ortaya konmasına yönelik bir süreç izlenmiştir. Çalışmada elde edilen sonuçlarla havayolu şirketlerinin uçuş operasyonlarında güvenliğin "daha iyi nasıl" sağlanır sorusuna cevap aranmaya çalışılmıştır.

Genel olarak, uçuş güvenliği dokümanlarına yapılan güncellemeler ağırlıkla reaktif, diğer bir ifadeyle meydana gelen güvenlik olaylarının değerlendirilmesi sonucunda "etki-tepki" yolu ile gerçekleşmektedir. Ancak, güvenlik konusunun akademik bir bakış açısıyla mevcut uygulamaları değerlendiren ve meydana gelen güvenlik olaylarının önlenmesine yönelik bir "proaktif" yöntemle ele alınması gerekmektedir. $\mathrm{Bu}$ kapsamda, uçuş güvenliği literatürüne, uçucu bir gözle fark edilen güvenlik aksaklıkların tespitinin ve mevcut güvenlik mevzuatının akademik olarak incelenerek güvenlik dokümanlarına güncelleme sağlanmasının katkı sağlayacağı değerlendirilmektedir. $\mathrm{Bu}$ katkıdaki en orijinal durumun akademik yaklaşımla yapılan bir araştırmanın uçucu gözüyle yorumlanması olduğu düşünülmektedir. Buradan hareketle, çalışmanın asıl amac1 hava yolu işletmelerinin güvenlik dokümanlarına ithal edilmek üzere hazırlanacak bir öneri setinin oluşturulması olarak belirlenmiştir.

$\mathrm{Bu}$ araştırma aynı zamanda uçuş güvenliğinin uçuş emniyetini tamamlayan bir etken olduğunu da ortaya çıkarmaya çalışmıştır. Bu kapsamda günümüzdeki uçuş güvenliği uygulamaları ayrıntılı bir şekilde teorik ve pratik düzeylerde incelenmiştir. Öncelikle uçuş operasyonlarında ICAO Uluslararası Sivil Havacılık Kuruluşu- International Civil Aviation Organization (ICAO) ve ulusal (Türkiye'de SHGM) otoriteler tarafindan tarafindan belirlenmiş "güvenlik standartları"ele alınmış, bu standartların operatör konumunda olan havayolu şirketleri tarafindan yapılan uygulamaları incelenmiştir. Daha sonra, terörist grupların havacılık endüstrisindeki güvenlik açıklarından faydalanarak 11 Eylül saldırılarından itibaren yaptıkları terör saldırıları bir arşiv çalışması şeklinde irdelenerek, uçuşlardaki güvenlik zafiyetleri anlatılmaya çalışılmıştır.

Çalışmanın "uçuş güvenliği" alanına olan katkısının havayolu şirketlerinin uçuş güvenliği birimlerinde yer alan yönetici ve çalışanlarının, uçuş personelinin (pilot ve kabin görevlisi) güvenlik bilinçlerini arttırmak, mevcut güvenlik uygulamalarını anlamak ve bu uygulamaları daha iyi duruma getirecek prosedürlerin oluşturulmasını veya güncellmesini sağlamak olacağ değerlendirilmektedir. Çalışmanın uçuş güvenliğini araştıran akademisyenlere ve güvenlik literatürüne, özgün ve uygulamaya yönelik bir perspektif sunacağı düşünülmektedir.

\section{2. Çalışmanın Araştırma Yöntemi}

Araştırmanın amacı, hava yolu işletmelerindeki güvenlik uygulamalarını iyileştirmek için hava yolu şirketlerinde çalışan güvenlik çalışanlarının, yöneticilerin ve pilot ve kabin görevlilerinin uçuş dokümanlarının güvenlik bölümlerine ithal edilmek ve kurumsal seviyede farkındalık yaratmak üzere bir "uçuş güvenliği öneri seti” oluşturmaktır. Bu 
amaca ulaşmak için nitel araştırma yöntemlerinden arşiv tarama ve örnek terör olaylarıyla ilgili yapılan incelemeler yolu ile veri toplanmaya çalışılmıştır. $\mathrm{Bu}$ verilerin içerik analizi yapılarak yorumlanmasında ve bulguların oluşturulmasında araştırmacının havacılık sektörü içinde olmasının da faydası olmuştur.

Bilindiği gibi nitel veriler, bir konuyu ölçmekten ziyade tanımlamaya çalışan bilgileri ayrıntılı bir şekilde toplayan izlenimler, görüşler ve fikirlerden oluşur [7]. Nitel araştırma ile var olan bir sistemde ya da uygulamada nelerin gözden kaçırılmış olduğu, mevcut duruma iyileştirme yapmak için nelerin yerine getirilmesi gerektiği sorularına cevap aranmaya çalışılmaktadır [8]. Nitel bir çalışmadan elde edilen bulgular ile konu hakkındaki genel uygulamalar ve düşünceler hakkında bilgi sahibi olunur, sonrasında ise ulaşılan bilgiler 1 şı̆̆ında özgün bir öneri seti oluşturulmaya çalış1ır [9]. Nitel araştırmalarda araştırmacının rolü/kimliği araştırma sürecini doğrudan etkilemektedir. Dolayısıyla araştırma yöntemi kısmında "havacı bakış açısını araştırmacının rolü altında ifade etmesi bilimsellik açısından daha anlaşılır olacaktır."

Nitel araştırmanın yukarıda sayılan bu özellikleri sayesinde çalışmamıza esas olan veriler iki basamaklı olarak elde edilmiştir. Bu kapsamda öncelikle havayolu şirketlerinin güvenlikleriyle ilgili ulusal ve uluslararası güvenlik prosedürleri ve mevzuatı incelenmiş, şirketlerin güvenlik usulleri tanımlanmıştır. Böylelikle güvenlik uygulamalarıyla ilgili mevcut veriler elde edilmiştir. Sonrasında ise ulusal ve uluslararası güvenlik mevzuatına rağmen, 2001-2017 yılları arasında meydana gelen uçuşla ilgili önemli terör olayları incelenerek bir durum tespiti yapılmaya çalışılmıştır. $\mathrm{Bu}$ sayede de güvenlik konusunda iyileştirme yapılması için yaşanmış örnek terör olaylarını konu alan veriler toplanmıştır. İşte tam bu noktada, mevcut uçuş güvenliği uygulamaları uluslararası bir dokümantasyon ve standartlarda olmasına rağmen, uçuşla ilgili terör faaliyetlerin nasıl meydana geldiği ve bu faaliyetlerden kaynaklanan güvenlik açıklarının asgari düzeye indirilmesi için nelerin yapılması gerektiği sorularına çalışmada cevap aranmaya çalışılmıştır. Diğer bir ifadeyle iki basamaklı veri toplama ve bunların yorumlanması sonrasinda elde edilen bulgular ile hava yolu şirketlerinin uçuş güvenlik dokümanlarına ve güvenlik birimlerine yönelik önerilere ulaşılmıştır.

Araştırma süresince izlenen bilimsel veri toplama ve analiz etiğine sadık kalınması konusunda bir taviz verilmemiştir. Özellikle çalışmada inandırıcılık (trustworthiness) kriterini yerine getirebilmek için inanılırlık, güvenilebilirlik, onaylanabilirlik ve aktarılabilirlik kısıtlarına bağlı kalmaya çalışılmıştır[10]. Araştırmanın geçerliliğini sağlamak üzere belirlenmiş olan bilimsel strateji ile bulguların kabul edilebilirliğini sağlamak üzere Creswell'in [11] işaret ettiği gibi araştırmanın geneli için çeşitleme stratejisi uygulanmıştır. Bu çeşitleme ile elde edilen verilerin analizinde ulaşılan bulguların geçerli ve güvenilir olması, sonuçların doğruluğu ve araştırmacının yetkinliği hakkında titiz davranılmıştır. Yine Cresswell'in önerdiği gibi araştırmacının sahip olduğu kültürel özellikleri ile bir uçucu personel olarak havacilık ve eğitimcilik deneyimleri sayesinde problem seçiminden problemin çözüm yöntemine, araştırmacının nasıl veri topladığına, olayları nasıl yorumladığına, araştırma süresince neyi bekleyip neyi elde etmeyi umduğuna kadar çalışmanın bütün yönlerinin şekillendirilmesinde etkili olmuştur.

Sonuç olarak bu çalışma nitel araştırma tekniği dinamikleri ile tamamlanmış uçuş güvenliği konusunda hava yolu şirketlerinin prosedürleri ve meydana gelen terör olayları incelenerek hava yolu şirketlerinde güvenlik uygulamalarının iyileştirilmesi için bir "güvenlik öneri seti" oluşturulmaya çalışılmıştır.

\section{Havayolu Taşımacılığında Güvenlik Kavramı}

\subsection{Uçak Güvenliği}

Havacılık endüstrisinde uçak güvenliğinin ayrı bir yeri vardır. Emniyetli olmanın yanında güvenli olarak yapılan uçuş operasyonları, ilgili havayolu şirketine ve o şirketin bağlı bulunduğu ülkeye, rekabet gücü verir ve güvenli olma özelliği katar. Uçak güvenliği, havaalanı güvenliği ve hava trafik güvenliği ile birlikte uçuş güvenliği binasını oluşturur. Burada uçak güvenliği uçağın yerde ve havada güvenlik içinde olmasını, havaalanı güvenliği, havaalanın her türlü tehdit ve saldırıya karşı korunaklı olduğunu, hava trafik güvenliği ise uçuş operasyonu içinde yer alan uçakların hava 
trafiği içinde her türlü siber ve fiziki saldırılara karş1 güvenli olduğunu ifade eder [12].

Özellikle 11 Eylül saldırılarından sonra uçuş ve uçak güvenliği konuları üzerine olan çalışmalar hız kazanmış ve $A B$ ülkelerinde konuyla ilgili olay analizleri yapılmasına ağırlık verilmiştir. Sektörde yaşanan gelişmelere bağlı olarak havayolu taşımacılığının yolcu ve kargo olarak artmış, Şekil 1 'de yer aldığı gibi dünyada 2019 yılında yaklaşık 40 milyon uçuş seferi gerçekleşmiştir.

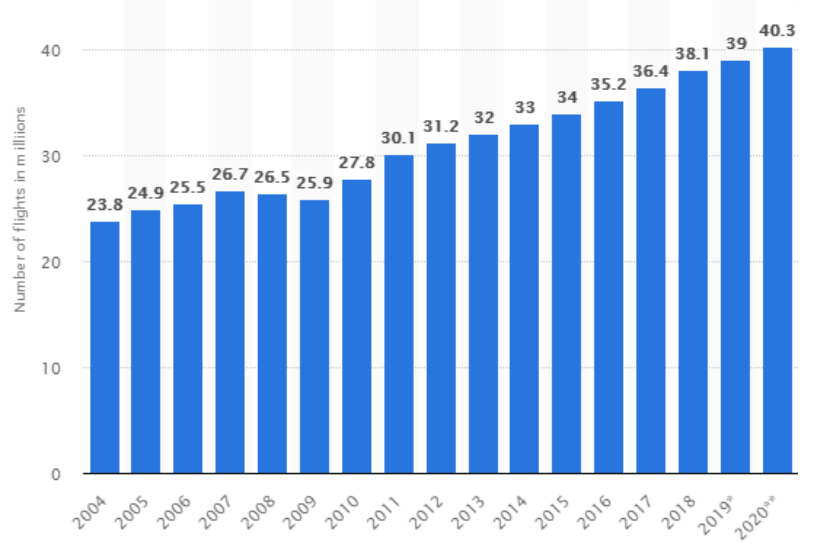

\section{Şekil 1: 2004-2020 Yılları Arasında Yapılan Uçuş Sayısı [13]}

Böylelikle de havayolu taşımacılığı ekonomik olarak geçmişe göre dünya ekonomisinde daha fazla bir yere sahip olmuştur. Ancak, 11 Eylül saldırılarıyla beraber uçakların terör potansiyeli bulunan bir saldırı aracı olarak kullanılmaya başlanması uçak güvenliği konsundaki çalışmaları akademik araştırma seviyesinin ötesine taşımıştır $[14]^{1}$. $\mathrm{Bu}$ saldırıdan sonra uçuş güvenliği çalışmaları, havacılık operasyonlarının güvenli yapılabilmesi için çare bulma çabaları olarak görülmeye başlanmıştır.

Uçak güvenliği öncelikle havaalanlarındaki güvenlik uygulamaları ile başlar. $\mathrm{Bu}$ kapsamda uçağa alınacak olan tüm yolcu, kargo ve uçuş ekipleri belirlenmiş güvenlik aramalarından geçerler. Güvenlik aramaları havaalanı girişlerinde ve uçağa binilmeden önce yapılır. Havaalanındaki

\footnotetext{
1 Özellikle 11 Eylül Saldırılarından sonra İsrail ve ABD'de yapılan uçuşlarda Air Marshall- Hava Güvenlik Personeli görevlendirme uygulaması başlatılmıştır. Elde edilen istihbarat
}

yolcu arama cihazları, X-Ray taraması, s1v1 maddelerin taşıma limitlerine uygun olup olmadığı, uçak içine ve uçağın kargo bölümünde taşınacak bagajların taşınma limitleri güvenlik önlemleri tedbirlerinden bazılarıdır.

Uçağa binmeden önce, güvenlik sağlamak amacıyla uçuş ekiplerinin de mutlaka geçerli bir apron kart1, yolcuların ise kendi isimlerine tahsis edilmiş uçak biniş kartına sahip olmaları gereklidir. Uçuş öncesinde uçağa yüklenecek her türlü kargo ve kateringin de güvenlik kontrollerinin yapılmas1 bir zorunluluktur. Uçuş öncesi yapılan bu güvenlik kontrollerinin ana sorumlusu havaalanı güvenlik birimi ile İçişleri Bakanlığı'na bağlı Emniyet güçleridir[15].

Uçuş öncesi havaalanında yapılan yolcu ve kargo güvenlik kontrollerinin yanında, uçuş ekibi tarafından uçağın her sefer öncesinde güvenlik aramasının yapılması gereklidir. $\mathrm{Bu}$ güvenlik kontrolleri, kanuni mevzuat gereği, havayolu şirketlerinin ulusal ve uluslararası havacillk otoritesinin belirlediği standartlara göre hazırladıkları "Uçak Güvenlik Araması Çeklisti"'ne göre yapılır[16]. Uçuş ekipleri tarafaından "security check" olarak adlandirılan bu aramada kabinde bulunan bagaj yerleştirme bölümleri, lavabolar, koltuk cepleri, çöp kutuları ve kabin içinde ulaşılabilecek heryer ayrıntılı bir şekilde kabin ekibi tarafından aranır. Benzer detayda kokpit ve uçağın dış bölümü de kokpit ekibince aranır, kontrol edilir. Yer hizmet görevlisi de uçağın kargo bölümünün aramasını yapar [17]. Uçak uçuşa gitmeden önce bu aramalar tamamlanır, "security form" lar kabin amiri, harekat memuru ve kaptan pilot tarafindan imzalanarak, ilgili form uçuşun resmi dokümanlarının yer aldığ 1 uçuş dosyasında muhafaza edilir. Bu uygulama ICAO, EASA, FAA ve SHGM uygulamasidir.

Yolcuların uçağa alınmaları sırasında da güvenlik kontrol ve aramaları devam etmektedir. Bu kontroller ICAO ve SHGM talimatlar1 doğrultusunda hazırlanan hava yolu işletmelerinin operasyon manuellerine göre yapılmaktadır. Kabin

ve bu doğrultuda belirlenen tehdit seviyesine göre devletin güvenlik birimlerine bağlı olarak çalışan bu kișiler uçak içinde silahlı ve gerekli yetkilere haiz olacak şekilde uçuş ekibine dahil edilmişlerdir. 
ekiplerinin yolcuların uçağa gelişleri sırasında "yolcu profillerini" incelemeleri, alkollü ya da uçuş güvenliğine tehdit olabilecek yolcuların uçağa alınmaması, sınır dışı yapılan (deportee) ya da ülkeye alınmayan (inadmissable) yolcuların kontrolleri, transit yolcuların güvenlik işlemleri hava yolu şirketlerinin uçuş öncesi güvenlik kontrolleri uygulamalarındandır.

$\mathrm{Bu}$ kapsamda uçak güvenliği kapsamında alınacak tedbirlerden bazıları aşağıda yer aldığ gibidir:

- Uçuş ekibinin kimlik kartlarının uçuş görevleri sırasında görünür bir şekilde takılı olmas1,

- Yolcu profillerine dikkat edilmesi, tehdit olabilecek yolcularla ilgili proaktif tedbirlerin alınmas1,

- Uçuşla ilgili yer ve uçuş ekiplerinin gerekli güvenlik eğitim sertifikalarının her zaman geçerli olmas1,

- Kokpite giriş çıkış usullerinin güvenlik kaygıları doğrultusunda bir prosedür haline getirilmesi ve bu prosedürün disiplinli bir şekilde taviz verilmeden uygulanması,

- Sahibi olmayan bagaj ya da eşyanın titizlikle kontrol edilmesi [17].

\subsection{Uçuş Güvenliği}

Uçuş güvenliği, uluslararası anlaşmalar ile belirlenmiş uçuş sırasında meydana gelebilecek "kanunsuz müdahale" kavramına dayanır [18]. Hukuki bir kavram olan kanunsuz müdahale: "tehditkar olsun ya da olmasın, uçakta uçuş emniyetini tehlikeye atan, uçaktaki disiplini veya düzeni bozan her türlü davranış ve tavırlar"dır [19]. $\mathrm{Bu}$ tanımdan hareketle uçuşta güvenlik "uçakta uçuş emniyetini tehlikeye atan, yolculara, uçuş teçhizatına zarar verecek, yaralayacak, hatta insanların ölümüne sebep olacak bilinçli olarak yaratılmış tehlikelerden korunmaktır" şeklinde ifade edilebilir.

Uçuş operasyonları sırasında uçuş güvenliğini ilgilendiren ve uçuş ekibi tarafından uçuş güvenliği ya da kanun dışı müdahale kapsamında uluslararası mevzuat ile belirlenmiş üç ana tehdit bulunmaktadır [20]. Bunlar:

- Kural Dişı Yolcu

- Uçak Kaçırma

- Bomba Tehdidi olarak siralanabilir.

\subsubsection{Kural Dışı Yolcu}

Kural Dışı yolcu uçak içindeki genel davranış ve emniyet kurallarına aykırı hareket eden, uçak içindeki genel disiplini bozan, huzursuzluk çıkaran, sözle ya da hareketleriyle saldırgan bir tavır içinde olan yolculardır. Bu tür yolcular mümkünse uçağa gelmeden kabin ve yer hizmetleri personeli tarafından "profilleme" ile belirlenmeli ve uçağa alınmamalıdır. Kural dışı yolcular, bazı durumlarda hava korsanları olma potansiyeline sahip olmaları veya uçağın güvenlik sebebi gereği destinasyonu dışında bir yere inmesine sebep olmaları yüzünden hassasiyetle ele alınmalıdırlar.

\subsubsection{Uçak Kaçırma (Hijack)}

Uçak kaçırma, siyasal, etnik ve ideolojik mesajların daha sansasyonel bir şekilde dünya kamuoyuna bildirilmesi için uçak korsanları tarafından başvurulan bir yöntemdir. Uçak kaçırma eylemi sırasında hava korsanları uçağın kontrolünü mutlak bir şekilde ele geçirirler. Bir uçak kaçırılması sırasında uçuş ekibi ve eylemin gerçekleştiği ülke otoritesi, uçağın indirilen meydandan başka bir yere gitmeyecek şekilde tedbir almalı ve güvenlik güçleri ile işbirliği içinde olunmalıdır.

\subsubsection{Bomba Tehdidi}

Bomba Tehdidi, uçağın içine uçuş sırasında ya da uçuş öncesinde bomba yerleştirilmesi ve bombanın patlatılmaya teşebbüs edilmesidir. Her ne kadar yapılan istatistiklere göre bomba tehditlerinin \%99'u sahte ihbar olarak çıssa da her ihbar ciddiye alınmalıdır [20]. Gerçek olarak algılanılan bir bomba tehdidi ile karşıllaşıldığında en kısa zamanda, ilgili güvenlik birimleriyle koordine kurularak iniş yapılmalıdır.

Özellikle bomba tehdidine yönelik olarak yolcular üzerine yapılan güvenlik aramalarının yanında kargo bölümüne yüklenen malzemelerin de 
güvenlik tarayıcıları tarafından aranması, bomba ya da uçak güvenliğine tehdit tehlikeli maddelerin bu şekilde yapılacak bir kontrol sonrasında ayıklanması önemlidir.

\subsection{Uçuş ve Uçak Güvenliğinde Karşılaşılan Sorunlar}

Uçuş güvenliği sağlanması vazgeçilmez bir ihtiyaçtır, ancak bunun maddi ve manevi olarak bazı maliyetleri bulunmaktadır. Öncelikle yolcular ve uçuş ekipleri için uçağa ulaşmak, güvenlik tedbirlerinin ayrıntılı olması ve güvenlik kapılarının geçişinin uzun zaman alması sebebiyle zorlaşmıştır. Güvenlik tedbirlerinin daha ayrıntılı bir hale gelmesi, havaalanı işletmesinin daha maliyetli olarak yürütülmesine, teknolojiye olan bağımlılı̆̆ın artmasına, güvenlik konusunda daha yetkin olan çalışanlara ihtiyaç duyulmasına ve havaalanlarında uzun zaman alan güvenlik uygulamalarının bazı durumlarda uçuş operasyonlarının gecikmesine, bunun yanında da yolcuların uçaklarını kaçırmalarına sebep olmaktadır. Örnek olarak; Londra uçuşlaırında gözlendiği üzere, Heatrow havalimanında yolcular dışında, uçuş ekiplerine yapılan ayrıntılı güvenlik uygulamaları, sıv1 kısıtlamaları, hatta uçuş ekiplerinin giyim aksesuarlarına (kravat iğnesi, küpe, kolye, kol saati, vb.) yapılan denetlemeler sonrasında uçuş ekiplerinin uçağa gelmeleri bazı zamanlar oldukça uzun sürmekte ve uçaklar seferlerinde gecikme yaşamaktadırlar.

Uçak güvenliğinde bazı tehdit ve zorluklar bulunmaktadır. Bunlar:

- Havalimanlarının fiziki güvenlikliklerini sağlamak için teknolojik bir altyapı oluşturmak, bu kapsamda izleme ve biometrik sistemlere ağırlık vermek,

- Kargo ve kabinde taşınacak uçuşa yasak malzemelerin bulunması için gerekli teçhizat altyapısını hazırlamak

- Bilgi işlem altyapısına sahip olmak ve yolcu bilgilerini tasniflemek,

- Havaalanı çalışanların güvenlik soruşturmalarını yapmak, kimlik ve apron kartlarını doğrulamak
- Uçuş trafiğinde tehdit olacak yerden atılan füze, lazer, mikrodalga silah sistemlerine karş1 tedbir almak olarak sıralanabilir [21].

Yukarıda yer alan zorlukların üstesinden gelmek için özellikle teknolojiden yararlanmanın önemli olduğu, güvenlik konusunda değişik alanlarda uzmanlık sahibi olan kurumların genel bir güvenlik portföyü içinde bilgi ve tecrübe paylaşımında bulunmaları gerektiği, akıllı ve klasik tehditlere, siber saldırılara karşı olan önlemlerin arttırılması gerekmektedir. $\mathrm{Bu}$ önlemlerin yerine getirilmesi için mali kaynak ayrılmasının önemli olduğu, güvenlik yatırımlarının yapılması gerektiği, havayolu şirketlerinin ve politikacıların güvenlik konusuna olan ilgisinin ve desteğinin arttırılmasına ihtiyaç duyulduğu, gerekli yönetmelik ve prosedürlerin acilen gözden geçirilmesi ve sürekli olarak güncellenmesi gereklidir.

\section{Uluslararası Havacılık Kurallarına Göre Uçuş Güvenliği}

Günümüz havayolu taşımacılığına dayanak olan en önemli anlaşma 1944 yılında ICAO'nun kurulmasıyla sonuçlanan ve Türkiye'nin de taraf olduğu Chicago Anlaşmasıdır. $\mathrm{Bu}$ anlaşmanın eklerine göre, uçuş ve uçak güvenliği konusunda alınacak önlemlerde üye ülkeler arasında güven ve karşılıklı anlayış esas alınmıştır[22]. ICAO'da yer alan güvenlikle ilgili maddeler ise 1963 Tokyo Konvansiyonu ile genişletilşmiştir. Tokyo Konvansiyonu daha sonra Kanada'nın Montreal kentinde 04.04.2014 tarihinde imzalanan ve 26.10.2017 tarihinde TBMM'de 7057 say1lı kanunla onaylanan "Hava araçlarında işlenen suçlar ve diğer bazı eylemlere ilişkin Tokyo sözleşmesini tadil eden protokol" ile güncellenmiştir. Söz konusu protokolle, uçuş opersyonlarındaki genel güvenlik konuları, yargilama yetkisi, kaptan pilotun yetkileri, hava araçlarında işlenen suçlar, hava polisi yetki ve sorumlulukları, hava aracının inişine neden olan yolcudan zararların tazmini gibi konularda düzenlemeler yapılmıştır[23]. Burada aynı zamanda uçuş operasyonlarının yapılırken alınacak önlemler üye ülkelerin sorumluluğundadır. Üye ülkeler güvenlikle ilgili olarak;

- Kendi hava sahalarındaki güvenliği,

- Tehdit analizi yapmayı, 
- Havaalanı güvenliğini sağlamayı,

- Uçuş operasyonu yapan şirketlerin güvenlik programlarını denetlemeyi,

- Personel güvenlik soruşturması yapmayı,

- Güvenlik eğitimleri vermeyi, güvenlik sertifikasyonlarını tazelemeyi,

- Kalite kontrol yapmay1 ICAO Annex 17 “ Security Manual for the Safeguarding of Civil Aviation Against Acts of Unlawful Interference (Doc 8973 - Restricted) and the Aviation Security Training Packages (ASTPs)" dokümanına göre düzenlemek zorundadırlar.

\subsection{ICAO'nun Güvenlik Standartları}

ICAO'nun genel olarak uçak güvenliğiyle ilgili belirlediği standartlar aşağıda yer aldığ gibidir[1]:

- Kokpit kapısı uçuş operasyonlarından itibaren kapalı ve kilitli olmalıdır.

- Kokpit kapısı, kalkış ağırlığı 45500 kg.'nin üzeri ya da 60 yolcudan fazla yolcu taşıma kapasitesine sahip tüm uçaklarda her türlü mermi, şarapnel vb. gibi silah tesirlerinden korunaklı olmalı, kokpit içinden manuel olarak kilitlenebilmelidir.

- Uçakta yolcu alımından önce mutlaka "security check=güvenlik araması" yapılmalı uçağın koltukları, bagaj yerleştirilen koltuk üstü dolapları, lavaboları, koltuk araları ve altları ve diğer uçak bölümleri titizlikle aranmalı,

- Uçakta bomba arama çeklisti bulundurulmal1,

- Bomba hasarının en az risk bulunduran (LRBL-Least Risk Bomb Location) uçak bölümü belirlenmeli,

- Havayolu şirketleri kendi güvenlik standartlarını belirten bir dokümantasyona sahip olmalıdırlar.

\subsection{ICAO'nun Güvenlik Eğitim Programları}

Uçak güvenliğini sağlamada var olan faktörlerden en önemlilerinden biri eğitimdir. ICAO'nun belirlediği standartlar dikkate alınarak havacılar için güvenlik eğitimleri oluşturulmaktadır. Bu eğitimlerde uçuş ekiplerinin güvenlik olaylarını daha oluşmadan engelleyecek hareket tarzlarının yerine getirilmesi amaçlanır. Güvenlikle ilgili eğitim programlarında aşağıda yer alan konular işlenir [1]:

- Bir güvenlik olayınının önem derecesini belirleme,

- Ekip içi iletişim ve koordinasyon,

- Uygun kendini savunma yöntemlerinin belirlenmesi,

- Otorite tarafından izin verilmiş ölümcül olmayan savunma aletlerini kullanabilme,

- Terörist ve uçak kaçırma eylemi gerçekleştirenlere karşı müdahale metotlarının öğrenilmesi,

- Uçakta bomba ile mücadele stratejilerinin bilinmesi,

- Güvenlik olaylarının raporlanması.

\section{Uçak Güvenliğini Tehlikeye Düşüren Terör Olayları}

Buraya kadar yapılan açıklamalarda uçuş güvenliğinin sağlanması için ilgili otoriteler tarafından belirlenmiş olan standartlar, eğitim programları, yönetmelikler ve havacılık endüstrisinin güvenlik kısıtları anlatılmaya çalışıldı. Ancak, güvenlik konusu havacılık endüstirisinde yaşanan güvenlik olaylarına bağlı olarak sürekli gelişmektedir. Uçuş operasyonlarında "uçağa gelen sarhoş yolcudan uçağı ele geçirmeye çalışan hava korsanına" kadar güvenliği ihlal etmeye çalışan grup ya da şahısların var olduğu düşünüldüğünde, güvenlik konusudaki bir takım ihtiyaç ve zafiyetlerin bazı terör eylemerinden sonra gündeme geldiği görülmektedir. $\mathrm{Bu}$ noktadan hareketle, çalışmamızın bundan sonraki bölümünde 20012017 yılları arasında meydana gelmiş olan önemli terör ve güvenlik olay örnekleriyle, alınan her türlü güvenlik önlemine rağmen, uçuş operasyonlarında güvenliği zafiyete düşürücü kişi ve eylemlerin olduğu anlatılacaktır.

\subsection{Uçak Güvenliğinde Terörist Saldırı Örnekleri}

Havacılık Endüstrisine olan terör saldırıları yeni karşılaşılan bir terör yöntemi değildir. Özellikle 1960'lı yıllarda hava yolu taşımacılığının artmaya 
başlaması, bölgesel krizlerin sonunda ortaya çıkan özellikle Filistin Davası gibi kangren olmuş sorunların terörist gruplarca küresel boyuta taşınma çabaları sonucunda, araç olarak uçaklar seçilmeye başlanmıştır. Uçakların dünya genelinde yapılan terör saldırılarında kullanılması, uçak güvenliğini daha önemli bir hale getirmiştir. Özellikle 11 Eylül saldırılarından sonra uçakların terörizmin bir aracı olarak kullanabileceği anlaşılmıştır. Bu saldırının başarıya ulaşması, terör eylemlerinde yeni bir çı̆̆ır açması ve "silah" olarak da uçakların kullanılmış olması uçuş güvenliği konusunun daha ciddi ve dikkatli bir şekilde ele alınmasına sebep olmuştur.

11 Eylül saldırlarının başarılı bir şekilde sonuçlanmasından sonra, terörist gruplar tarafından uçak kaçırma eylemleri yerine uçakları patlatma ya da terör eylemleri için ele geçirme eylem teşebbüsleri artış göstermiştir. Bu bağlamda; İngiliz El-Kaide teröristi Richard Reid, 11 Eylül saldırılarından sadece iki hafta sonra ayakkabısına sakladığı patlayıcı ile Paris-Miami seferini yapan American Airlines seferine yolcu olarak binmeye çalışmış ve yakalanmış, 2006 yılında ABD ve Kanada'dan Londra'ya sefer yapan uçaklardan aynı anda 17'sinde meşrubat kutuları içindeki patlatyıcılar ile yine El-Kaide tarafından terör eylemi girişimi önlenmiş, Ekim 2010'da Yemen'den ABD'ye giden bir kargo uçağına yerleştirilmiş patlayıcı madde içeren kutuların bir kısmı Dubai'de, bir kısmı da İngiltere'de tespit edilerek muhtemel terör saldırıları önlenmiştir[24].

$\mathrm{Bu}$ tür olaylar, her ne kadar önlemiş olsa da terörist grupların uçakları bir "terör silahı" olarak kullanma motivasyonlarının ne kadar fazla olduğunu anlatmaktadır. Uçakların yanında uçakların bulunduğu apron, terminal, havaalanı ve binalarının terör saldırıları için açık bir hedef oldukları anlaşılmaktadır. Burada terör grupları saldırı için gerekli insan gücünü havaalanlarında çalışan sempatizanlarla internet ve sosyal medya aracılığı ile elde etmektedirler[25].

En dikkat çekici terör eylemlerinden biri de 31 Ekim 2015 tarihinde Sharm El Sheik'ten St. Petersburg'a uçuş yapan Rus Airbus A321 uçağının düşürülmesi eylemidir. Uçağın kargo bölümünde İşiD üyeleri tarafından kola kutusu içine yerleştirilmiş olan bombanın patlatılmasıly 224 yolcunun kaybedilmesine sebep olmuştur[26]. Bu saldırının hemen sonrasında benzer bir saldırı da 3 Şubat 2016 tarihinde Somali'de İșiD benzeri bir grup olan El-Şahab El-Mücahit tarafından, uçağın kalkışından hemen sonra yerleştirilmiş bombanın patlatılması ile yapılmıştır. Bu saldırıların ardından, bagaj yüklemesi yapan ya da uçak içi temizlik görevlilerinin güvenlik kleransları sorgulanmış, ayrıca uçak içinde kabin ve kargo bölümlerinde yapılan "Security Check- Güvenlik Araması" kontrollerinin önemini ortaya çıkarmıştır[27]. Görüldüğü gibi güvenlik açısından uygun olmayan kişilerin havacılık faaliyetlerinde çalıştırılması ve "uçak içi güvenlik kontrollerinin" tam olarak yapılmaması bu tür olaylara sebebiyet vermektedir.

Diğer bir terör saldırısı örneği ise uçuş öncesi uçuş ekiplerini, yolcularını ve terminal çalışanlarını hedef alan doğrudan havaalanlarına yapılan terminal saldırılarıdır. $\mathrm{Bu}$ tip terör kaynaklı güvenlik olayına verilecek ilk örnek 22 Mart 2016 tarihinde Bürüksel Havaalanının Dıș Hatlar Terminalinde İŞī tarafından gerçekleştirilmiştir [28]. Hemen sonrasinda ise, 28 Haziran 2016'da İstanbul Atatürk Havalimanı Dış Hatlar Geliş Terminalinde teröristler tarafından intihar bombası ve rasgele otomatik silahlarla ateş edilmesi ile düzenlenen bir terör eyleminde bulunulmuştur [29]. $\mathrm{Bu}$ saldırılardan sonra küresel boyutta havalimanlarına giriş usulleri, güvenlik önlemleri, havaalanına giriş yapan kişilerin X-Ray ve biyometrik taramaları, güvenlik güçleri tarafından alınması gereken tedbirler gözden geçirilmiştir.

Yukarıda verilen terör saldırıları örneklerinden de anlaşılacağı gibi, her seviye ve ideolojideki terör grupları uçakları birer terör aracı olarak kullanma konusunda tam bir motivasyona sahiptirler. Çünkü bu saldırılar yoluyla küresel boyutta hava yolu taşımacılığına zarar verirken, uluslararası kamuoyunda da ciddi bir şekilde ses getirirler. Güvenlik aşamalarını geçerek uçağa ulaşan ve burada terör saldırısında bulunan terörist gruplar uluslararası arenada hem propagandalarını yaparlar hem de diğer terörist gruplara kıyasla daha fazla prestij kazanırlar. Diğer bir ifadeyle, Filistin davasını terör yoluyla dünyaya duyurmaya çalışan terörist lider George Habbash'ın 1960 y1lında İsrail Hava Yolu Şirketi El-Al'ın Cezayir uçağının kaçırılması sonrasında basına verdiği “...bizim için 
bir uçağ kaçırmak, çatışma alanında 100 İsrailliyi öldirmekten daha değerlidir..” demeci [30] uçaklarla yapılan terör saldırılarının psikolojik ve medya etkisinin ne kadar fazla olduğunu özetlemektedir.

Günümüzde internet ve sosyal medyanın kullanımının artması, terörist grupların da kitlelere küresel erişim yollarını ve yapılarına adam kazanmalarını kolaylaştırmıştır. Özellikle İşīD gibi terör örgütlerinin otorite boșluğu olan Suriye ve Irak gibi ülkelerde varlık göstermeleri, dünyanın neredeyse her yerinden yeni terörist kazanmalarını ve destek bulmalarını kolaylaştırmıştır. Bu küresel terörizm altyapısı sayesinde uçuş güvenliğine ilişkin terör saldırıları da düzenlenebilmiştir. Brüksel saldırısının hemen ardından sosyal medyada yapılan propagandaların sonrasinda benzer bir saldırı Almanya'nı Köln Havaalanında'da Nisan 2016'da yapılmaya çalışılmıştır[31]. Ancak bu girişim başarılı olamamıştır. Burada da yerel sempatizan kişiler arasından devşirilmiş teröristler arası bilgi akışı ve iletişim internet ve sosyal medya üzerinden yapılarak terör eylemi girişiminde bulunulmuştur.

2015 yılında Uluslararası Karşı Terörizm Enstitüsü (International Institute for CounterTerrorism (ICT)) tarafından yapılan çalışma sonrasında havaalanlarında yapılan ișe alımlarında, adayların adli güvenlik soruşturmalarının mutlaka yapılması gerektiği ve özellikle sosyal medya paylaşımlarının takip edilmesinin önemli olduğu vurgulanmıştır. Bunun yanında havaalanlarındaki güvenlik tedbir ve yönetmeliklerinin mutlaka sürekli olarak gözden geçirilmesi, X-Ray, profiling $^{2}$, kamera ve takip gibi genel güvenlik tedbirlerine önem verilmesi, operasyon yapilacak destinasyonlardaki havaalanlarının güvenlik yeterliklerinin ülke ve şirket bazında takip edilmesi tavsiye edilmiştir[32]. $\mathrm{Bu}$ durum yukarıda bahsedilen 2015'teki Rus uçağının Sharm ElSheik'te düşürülmesi sonucunda yapılan soruşturmada 2016 Ocak ayında bombayı uçağa yerleştiren kargo görevlisi ve ona yardımcı olan El-

2 Profiling, kabin ve yolcu hizmetlerinde çalışanların gelen yolcular hakkında yaptıkları gözleme dayalı bir güvenlik tedbiridir. Profiling sonrası şüpheli olarak
Kaide sempatizanı iki polis memurunun yakalanması ile örneklendirilmiştir[33].

Ayrıca bu tür terörist örneklerine; Minneapolis - St. Paul Uluslararası Havalimanı'nda Abdifatah Ahmed adlı bir uçak temizlik görevlisinin terörist gruplarla ilişkisinin ortaya çıkması[34], ElMücahiddin grubuna ait terminal görevlisi Abdirahmaan Muhammed'in yakalanması[35], İşiD üyesi servis şoförü Shirwa Ahmed'in gözaltına alınması verilebilir[36].

Ancak alınan her türlü önleme rağmen, havalimanlarında zaman içinde oluşabilecek sempatizanlaşma durumuna da engel olmak, buralarda çalışan personeli sürekli olarak gözlem altında tutmak gerekebilir. Örnek olarak, Brüksel Havalimanı'nda temizlik 5 yıl boyunca işçisi olarak çalışan Najim Laachraoui, daha önce de AB Parlamentosu'nda çalışmasına, üstleri tarafından çok beğenilen bir çalışan olmasına rağmen 2016'daki saldırıda yer almıştır[37].

Havacılık sektörüne saldırıda bulunan teröristler, kendi ülkelerinde devşireleceği gibi, halihazırda çeşitli terörist gruplarda yer alan, aynı zamanda da vatandaşı olduğu ülkelere geri dönerek terör saldırılarında bulunabilicek kişiler de olabilirler. Bunu açıkça New York'ta bir radyo programında itiraf eden eski İ̧̧íD teröristi Abu alAyna al-Ansari, kendisinin Gazze'de IșsíD adına faaliyet gösterirken, dünyanın birçok yerinde IsşiD'in gizli elemanı olan kişilerin her an bir eylemde bulunacak şekilde hazır olduklarını itiraf etmiştir[38]. Aslında bu durum sadece havacıllk alanındaki terör saldırılarına ait bir durum değildir, bu tür "gizli" teröristler diğer alanlarda da eylemde bulunmaktadırlar, ancak havacılık hedefleri daha çok ses getirecek eylemlerdir. $\mathrm{Bu}$ yüzden terör grupları havacılık hedeflerine yoğunlaşmaktadırlar.

\subsection{Uçuş Güvenliğini Tehdit Eden Terör Saldırısı Çeşitleri}

görülen yolcular takibe alınır, gerekli görüldüğü durumlarda uçağa binmelerine engel olunur. 


\subsubsection{Terör Amaçı Roket Saldırıları}

Sivil uçaklar roket saldırılarına karşı oldukça savunmasızdırlar. Bu uçakların roketlere, yerden havaya atılan füzelere, omuzdan atılan "manpad”lere karşı hiçbir savunma tedbiri yoktur. Askeri uçaklarda bu tür tehditleri savuşturacak elekronik harp sistemleri, manevra çeşitleri ve uçak üstünde tak1lı "chaff ve flare (füzeyi hedefe ulaşmasında yanıltıcı karşı sistemler)" olmasına rağmen yolcu uçaklarında bu tür sistemler bulunmamaktadır. Yolcu uçakları özellikle iniş ve kalkış sırasında roket saldırılarına karşı oldukça savunmasızdırlar. Bu durumu bilen terörist gruplar firsat buldukları ve eylem yapmak istedikleri anlarda kolaylıkla bu yola başvurmaktadırlar. Ayrıca bu tür silahların temini ve eğitimi çok kolaydır, at ve unut konseptiyle kullanılan bu tür silahların kullanımı internet kaynaklarından bile öğrenilebilmektedir[39].

$\mathrm{Bu}$ tür birçok saldırı terör grupları tarafından yapılmıştır. Örneğin; 2002 yılında "Arkai” model bir yolcu uçağ 1 Kenya'dan İsrail'e olan uçuşu sırasında roket saldırısına uğramıș, PKK terör örgütü de kullandığı anti-tank füzleriyle İstanbul Sabiha Gökçen Havalimanına saldırıda bulunmuştur[40].

Havacılığın zarar görmesi ve havacılık faaliyetlerinin durması için bu tür füzelerle yapılan saldırıların doğrudan havalimanına ya da uçaklara yapılması gerekmemektedir. Havalimanlarının veya uçakların civarındaki hedeflere yapılan saldırılar da havacilık faaliyetlerinin durmasina sebep olmaktadır. Örneğin 2014 yılında Hamas'ın Tel Aviv'deki Ben Gurion Havalimanı civarındaki bir evi vurması sonucu birçok şirket geçici olarak buraya yaptıkları seferleri askıya almıştır[41]. Bunun sonucunda İsrail Sivil Havacılığı faaliyetleri durma noktasına gelmiş ve İsrail bayrak taşıyıcı şirket El-Al'ın uçuşları azalmıştır.

$\mathrm{Bu}$ tür saldırıların önlenmesi için havaalanı otoritesinin ya da uçuş birimlerinin ICAO kapsamında alacakları güvenlik tedbirleri yeterli olamayacağ1 bilinmelidir. $\mathrm{Bu}$ tür güvenlik tehditlerinin yok edilebilmesi için güvenlik güçleriyle kapsamlı bir istihbarat ve gözlem bilgisi paylaşımı gerekmektedir.

\subsubsection{Dron Kullanılan Terör Saldırıları}

Dronlar son zamanlarda, dünyanın hemen her yerinde birçok amaçla kullanılmaktadır. Her alanda olduğu gibi, terör örgütleri de saldırılarında dronlardan faydalanmaktadırlar[42]. Hatta bununla ilgili havayolu şirketlerinin uçuş eğitimlerinde dron saldırısı senaryoları, saldırı halinde yapılacak prosedürler işlenmektedir. Bazı durumlarda saldırı yerine uçakları korkutma ya da uçuş yollarından saptırmaya yönelik dron faaliyetleri de olabilmektedir. Bu duruma örnek olarak, 8 Ağustos 2015 tarihinde Tel Aviv Ben Gurion havalimanında alçalmakta olan "Brussels Airlines"a ait uçağın yanından geçen bir dron uçağın pas geçmesine ve başka bir meydana yönlenmesine sebep olmuştur[43]. İsrail Ulaştırma Bakanlığı özellikle havalimanları civarında uçurtulan bu tür dronların herhangi bir terör saldırısı için kullanılmasa bile, bazı bölgelerde uçurulmalarının yasaklanmasını ve bu tür dronları kullananların "dron lisansı"na sahip olmaları gerektiği konusunda bir rapor hazırlamıştır[44].

İsrail'in dron konusunda başlattığı bu inisiyatifin dünya genelinde de yankısı olmuştur. Örnek olarak NASA sponsorluğunda Temmuz 2015'de yapılan bir havacılık konferansinda Newark, New Jersey, Minneapolis, Minnesota, ve Austin'daki havalimanları yakınlarında uçurulan dronların iniş ve kalkış yapan uçakların emniyetini tehdit ettiği ve bu tür hava araçlarının acilen kontrol altına alınması gerektiği tavsiye edilmiştir. Bunun üzerine konferansa katılım sağlayan FAA (Federal Aviation Authority (Federal Havac1lı Dairesi)) harekete geçerek belli ağrılık ve özelliklerin üzerinde olan dronların mutlaka uçak gibi tescil ettirilmesini ve kullanıcılarının lisanslandırılmasını karara bağlamıştır[45]. Benzer bir şekilde, Türkiye'nin de TALPA- Türkiye Hava Yolları Pilotları Derneğiyoluyla dahil olduğu European Cockpit Association (ECA)- Avrupalı Pilotlar Topluluğu da Remotely Piloted Aircraft System (RPAS) Çalışma Grubu kurmuş ve bu grubun çalışmaları sayesinde $A B$ Havacılık Dairesinde tarafindan dronlar hakkında bazı düzenlemeler yapılmıştır[46]. Bu gelişmelere pararlel olarak Türkiye'de Sivil Havacilık Genel Md.lüğü (SHGM) İnsansız Hava Araçlarının (IHHA) uçurulması ile ilgili bir yönetmelik çıkarmış [47] ve 
bu tür araçların kullanılması hakkındaki lisanslardırma çalışmalarını hızlandırmıştır.

\subsubsection{Simülatör Tehdidi}

Simülatörler uçuş eğitimlerinin vazgeçilmez bir yardımcısı olduğundan dolayı uçaklara karşı ya da uçaklarla yapılacak her türlü terörist saldırıda yararlanılacak bir araçtırlar. Terörist gruplar gerek internet üzerinden kullanılabilen uçak simülasyonlarını gerekse de satın alınan uçak simülasyon yazılım ve donanımlarından faydalanarak uçak güvenliğini sarsan terör saldırılarında simülatörleri kullanmaktadırlar[48]. $\mathrm{Bu}$ bağlamda El-Kaide ve İŞİD teröristlerinin simülatörleri kullandığı, hatta Libya'nın Sirte şehrinde kurdukları simülatör merkeziyle uçuş eğitimleri verdikleri ortaya çıkmıştır[49].

Simülatörlerin terör eylemlerinde doğrudan kullanılması mümkün olmasa da, uçuşla ilgili terör eylemlerini yerine getirmedeki şartları yerine getirme ortamı oluşmaları bakımından simülatörler uçuş güvenliğini sağlamada dolaylı bir yer almaktadır. Simülatör tesislerine girişler havaalanlarına girişlerden kısmen daha kolaydır. Ayrıca ücreti karşılığında herhangi bir kişi pilot olmasa bile simülatör kiralayarak sanal ortamda gerçeğe yakın bir ortamda uçma imkanına sahip olmaktadır. $\mathrm{Bu}$ sebeplerden dolayı simülatörlerde de bazı güvenlik tedbirlerinin alınması gereklidir.

Yukarıda yapılan açıklamalar ışığında; simülatör tesislerine girişlerin de güvenlik kaygılarından dolayı kontrol altında olması, burada uçuş yapmak isteyenlerin amaçlarının kesin olarak belirlenmesi, şüpheli durumlarda güvenlik kuruluşlarına haber verilmesi ve simülatör tesislerinin güvenliklerinin havacılık otoritesi tarafından periyodik olarak denetlenmesi gerekmektedir.

\subsubsection{Uçuş Yapan Pilotlara Yönelik Lazer Tehdidi}

Uçak güvenliğini tehlikeye atan en kolay temin edilen ve kullanılan araçlardan biri de lazerdir. Öyle ki sadece oyun olsun diye çocukların, gençlerin havalimanları civarında kullandıkları lazer kalemlerindenden, teröristlerin uçuş güvenliğini tehlikeye atmak için direk olarak kokpiti hedef olarak kullandıkları güçlü lazer silahlarına kadar geniş bir spektrumda kullanılmaktadır. 2005 yılından beri FBI tarafindan yapılan bir istatistikte ABD'de günde ortalama 11 " uçaklara lazer s1kma" olayı ile karşı karşıya kalınmış, bu olayların da günümüze gelindiğinde 1000 kat kadar arttığ1 saptanmışıtır[50].

Lazer kullanımına bağlı olarak kokpitte yer alan pilotların geçici körlük yaşadıkları bilinmekle beraber, henüz uçaklara direk etkisi olan bir olaya rastlanmadığ 1 , rahatsızlanan pilotun yerini diğer pilotun aldığ 1 ve uçağın emniyetli bir şekilde indirildiği görünmektedir[51]. Ancak her iki pilotun da geçici körlük yaşadığ 1 durumlarda ölümcül bir kaza ile karşılaşılması işten bile değildir. Ayrıca, daha güçlü bir lazer silahı elde edildiğinde lazer saldırılarının boyutu değişebilecektir. Bunun için lazer tehdidine ciddi bir şekilde yaklaşılmalı yerel güvenlik güçlerinin desteğinde önlemler alınmalıdır.

\subsubsection{Siber-Terör Tehdidi}

Günümüzde tüm endüstrilerde olduğu gibi havacılık endüstirisinde de siber bilgi sistemleri kullanım oranı oldukça fazladır. Uçağın otomasyon sistemleri, yer kontrol üniteleri ile yaptı̆̆ 1 haberleşme, uçakların kontrolü, hava trafiğinin kontrolü vb. faaliyetlerin hemen hepsi siber ortamda yapılmaktadır. $\mathrm{Bu}$ yüzden siber saldırıların önlenmesi ve siber güvenlik konusu uçuş güvenliği ve emniyeti bakımlarından hayati derecede önemlidir.

Ayrıca yolcu olarak uçağa binerek uçağın bilgisayar sistemlerini "hackleme" faaliyetinde bulunan kişilerin de olabileceği göz ard1 edilmemelidir. Özellikle uçağın usb bağlantılarının, kablosuz internet imkanlarının kullanılarak bu tür eylemlerde bulunabileceği bilinmektedir[52]. Uçakların yolcular tarafından hacklenme olasılığ 1 az olduğu bilinmekle beraber, daha çok uçakların yönetimi ve planlanması aşamasında havayolu şirketlerine ve hava trafik kontrolörlerinin sistemlerine hackleme yapılması her zaman gündemde bir konudur. Örnek olarak, 2015 Haziran'da Polonya'nın LOT şirketinin uçak yönetim yazılımı hacklenmiş, uçaklar yerde kalmış, uçuş planları çıkarılamamış ve uçuşlar durma noktasına gelmiştir[53]. 
Siber-terör birçok radikal terör grubunun dikkatini çeken bir konudur. Etkilerinin geniş kapsamlı olmasından dolayı bu tür gruplar bünyelerine hacker'ları dahil etme çabaları, yetiştirme ve eğitim verme faaliyetleri terör grupları tarafindan yapılan faaliyetler arasındadır.

Uçak sistemlerine yönelik siber saldırıların yanında GPS sinyallerinin saptırılmas1, yok edilmesi, bu yolla seyrüsefer yapan İHA (İnsansız Hava Aracı) ve uçakların rotalarından saptırılarak kaza yapmalarının sağlanması başvurulan diğer siber saldırı örnekleri arasındadır. Örnek olarak, ElKaide'nin 2011 yılında Irak'ta ABD'nin İHA faaliyetlerini sınırlamak için GPS karıştırması yaptığı, 2016 yılında İsrail'e ait İHA'ların düşürülmesi için Gazze'den GPS karıştırması yapıldığı, aynı zamanda İsrail Savunma Bakanlığı hacklenerek önemli istihbarat bilgilerinin ele geçirildiği görülmekte, bu tür karıştırmaların o bölgelerde uçan sivil uçakların seyrüseferlerini de olumsuz olarak etkilediği anlaşılmaktadır[54].

Sonuç olarak uçak güvenliğine ilişkin olarak uçakların güvenliğine direk etkide bulunacak bir siber saldırı olasılığının henüz düşük bir seviyede olduğu, ancak; hava trafik yönetimi, uçak operasyon yönetimi, GPS sinyallerinin köreltilmesi yolu yapılacak siber saldırılara yönelik tedbirlerin alınması gerekmektedir.

\section{Bulgular}

Hava yolu işletmelerinde uçuş güvenliğinin iyileştirilmesi için bir öneri seti hazırlanması amacıyla yapılan mevzuat incelemesi ve örnek terör olaylarının içeriklerinin analizi sonrasında aşağıda yer alan bulgulara ulaşı1mıştır:

- Uçakların terör örgütlerinin birer silah aracı olarak kullanılmaya başlandığı 11 Eylül 2001 saldırılarından sonra, dünya çapında uçak güvenliğini arttırıcı ve global düzeyde işbirliği oluşturucu şekilde ICAO önderliğinde birtakım önlemler alınmaya başlanmıştır. $\mathrm{Bu}$ önlemler kapsamında çalışanların üniformaları, giriş kartları, güvenlik eğitimleri, havalimanı giriş çıkış, apron bölgesinde bulunma usulleri gözden geçirilmiş ve bir standarda bağlanmıştır.
- Havaalanındaki yolcu arama cihazları, XRay taraması, sıvı maddelerin taşıma limitlerine uygun olup olmadığ 1 , uçak içine ve uçağın kargo bölümünde taşınacak bagajların taşınma limitlerinin kontrolü gibi güvenlik önlemleri alınmaktadır, ancak bu önlemler terör eylemi yapacak ya da uçuştu güvenlik riski taşıyan kişilerin uçağa binmelerine engel olamamaktadır.

- Uçağa binmeden önce, güvenlik sağlamak amacıyla uçuş ekiplerinin geçerli bir apron kartı, yolcuların ise kendi isimlerine tahsis edilmiş uçak biniş kartı bulunmaktadır. Uçuş ekiplerinin ve yolcuların bu belgeleri kolaylıkla kopyalanabilmektedir.

- Uçuş öncesinde uçağa yüklenecek her türlü kargo ve kateringin de güvenlik kontrollerinin yapılması bir zorunluluktur. Örnek terör olaylarının içerik analizlerinde yükleme ve kontrol yapan personelin terör eylemi içinde bulundukları örnekler yer almaktadır.

- Uçuş öncesi güvenlik kontrolleri hava yolu şirketlerinin ulusal ve uluslararası havacılık otoritesinin belirlediği standartlara göre hazırladıkları "Uçak Güvenlik Araması Çeklisti”ne göre yapılmaktadır. Ancak bir şekilde uluslararası standartlara bağlanmış arama usulleri bulunmasina rağmen uçuşlarda güvenlik ihlali yaratan sahipsiz cep telefonu, tablet, ve diğer malzemelere rastlanmaktadır.

- Uçuş ve yer ekipleri tarafindan yolcuların uçağa binişleri sırasında güvenlik amaçlı şüpheli kişileri önlemeye yönelik "profiling" yapılmaktadır. Buna rağmen terör amaçlı olsun olmasın uçuşta yolculardan kaynaklı güvenlik olaylarına rastlanmaktadır.

- Hava yolu işletmelerinde yer alan pilot, kabin memuru, yer görevlisi, vb. tüm personele uluslararası mevzuat gereği periyodik olarak güvenlik eğitimleri 
verilmekte, kullanılan prosedürler de titizlikle uygulanmaya devam etmektedir. Ancak buna rağmen güvenlik olayları süregelmektedir.

- Uçuşta güvenliği tehdit eden üç ana tehdit, Kural Dışı Yolcu, Uçak Kaçırma, Bomba Tehdididir. Güvenlik uygulamaları bu ana tehditlere göre biçimlendirilmektedir.

- Güvenlik tedbirlerinin daha ayrıntılı bir hale gelmesi, havaalanı işletmesinin daha maliyetli olarak yürütülmesine, teknolojiye olan bağımlılığın artmasına, güvenlik konusunda daha yetkin olan çalışanlara ihtiyaç duyulmasına ve havaalanlarında uzun zaman alan güvenlik uygulamalarının bazı durumlarda uçuş operasyonlarının gecikmesine, bunun yanında da yolcuların uçaklarını kaçırmalarına sebep olmaktadır. Bunun için hava yolu şirketlerinin güvenlik uygulamalarında "güvenlik ve uçuşta etkinlik" dengesine ihtiyaç bulunmaktadır.

- Uçak güvenliği uygulamalarında;

- Teknolojik altyap1 oluşturmada ve biometrik sistemlerin kurulmasında,

- Uçuşa yasak malzemelerin bulunmas1 için gerekli teçhizat altyapısını hazırlamasında,

- Bilgi işlem altyapısına sahip olunmasinda ve yolcu bilgilerini tasniflenmesinde,

- Havaalanı çalışanların güvenlik soruşturmalarını yapılmasında, kimlik ve apron kartlarını doğrulanmasında,

- Uçuş trafiğinde tehdit olacak yerden atılan füze, lazer, mikrodalga silah sistemlerine karş1 tedbir alınmasında sorunlar bulunmaktadır. Bu sorunların üstesinden gelebilmek için teknolojik gelişmeleri takip etmeye havacılık tecrübesi olan uzmanlarla çalışmaya ihtiyaç bulunmaktadır.

- Uçuş operasyonlarında hava yolu işletmesi adına en yetkili kişi Kaptan Pilot'tur. Güvenlik anlayışında meydana gelen gelişmelere Kaptan Pilotun güvenlikle ilgili yetkilerinin güncellenmesine ihtiyaç vardır.

- Uçuş operasyonları uluslararası bir coğrafyada icra edilmektedir. Bu sebepten dolayı güvenlik konusunda ülkeler arası koordine ve bilgi paylaşımına ihtiyaç duyulmaktadır.

- İsrail ve ABD gibi güvenlik konusunda çok hassas olan bazı ülkelerde, potansiyeli olarak terör tehdidi bulunan uçuşlarında "Air Marshall- Hava Güvenlik Personeli" görevlendirme uygulaması bulunmaktadır.

- Uçuş güvenliğini tehdit eden en önemli konu terörist eylemlerdir. Terör eylemleri sadece uçak içinde değil, uçakların bulunduğu apron, terminal, havaalanı ve binalarında meydana gelebilmektedir.

- Teröristler, eylemleri için gerekli insan gücünü havaalanlarında çalışan sempatizanlarla internet ve sosyal medya aracılığı ile elde etmektedirler. Bu sebepten dolayı hava yolu şirketlerindeki çalışanların güvenlik soruşturmalarının sürekli olarak güncellenmesi gereklidir.

- Uçaklarla yapılan terör saldırılarının kamuoyu üzerinde psikolojik ve medya etkisi oldukça fazladır. Bunun için hava yolu şirketlerinin güvenlik birimleri ile basın yayın ve halkla ilişkiler birimlerinin güvenlik yönetimi ve güvenlik olaylarının kamuoyu üzerindeki etkilerinin azaltılması konularında ortak çalışma yapmalarına ihtiyaç vardır.

- Terör olaylarında internet ve sosyal medyanın kullanımının artması, terörist grupların da kitlelere küresel erişim yollarını ve yapılarına adam kazanmalarını kolaylaştırmıştır. Bundan dolayı hava yolu şirketlerinin devletin siber güvenlik birimleriyle iletişim halinde olmaları gerekmektedir.

- Hava yollarında uçan uçaklar roket saldırılarına karşı oldukça savunmasızdırlar. $\mathrm{Bu}$ uçakların roketlere, yerden havaya atılan füzelere, omuzdan atılan "manpad"lere karşı hiçbir savunma tedbiri yoktur. Bu tür tehditlerin var olduğu bilinen yerlerdeki uçuş operasyonları için 
güvenlik güçleriyle kapsamlı bir istihbarat ve gözlem bilgisi paylaşımı gerekmektedir.

- İHA'ların da terörist eylemlerde kullanılma imkanı bulunmaktadır. Bunun için tehdit olarak kabul edilecek özelliklere sahip olan dronların mutlaka uçak gibi tescil ettirilmesi ve kullanıcılarının lisanslandırılması gerekmektedir.

- Hava yolu şirketlerinin simülatör tesisleri terörist amaçlı eğitim alma faaliyeti için kullanılabilmektedir. Bunun engellenmesi için simülatör tesislerine girişlerinin de güvenlik kaygılarından dolayı kontrol altında olması, burada uçuş yapmak isteyen kişilerin maçlarının kesin olarak belirlenmesi, şüpheli durumlarda güvenlik kuruluşlarına haber verilmesi ve simülatör tesislerinin güvenliklerinin havacılık otoritesi tarafindan periyodik olarak denetlenmesi gerekmektedir.

- Uçuş sırasında pilotların görme yetilerine zarar verme amaçlı olarak lazer tehdidi bulunmaktadir. Bununla ilgili bilgi paylaşımına ve önleyici tedbirlerin alınmasına ihtiyaç bulunmaktadır.

- Uçuş güvenliğine doğrudan etkide bulunacak bir siber saldırı olasılığının henüz düşük bir seviyede olduğu görülmektedir. Ancak; hava trafik yönetimi, uçak operasyon yönetimi, GPS sinyallerinin köreltilmesi yolu yapılacak siber saldırılara yönelik tedbirlerin alınması gerekmektedir.

Çalışma kapsamında uçuş güvenliğine yönelik olarak elde edilen bulgular daha ayrıntılı bir çalışma ile çoğaltılabilir. Yukarıda bahsedilen doğrudan terör eylemlerinin yanında, uçuş operasyonlarında son zamanlarda sıkça karşılaşılan "uçakta bomba var" notları, seferdeki uçakla ilgili kimliği bilinmeyen kişiler tarafından yapılan sahte telefon ihbarları, uçakta unutulan ancak uçuş sırasında bulunan cep telefonları, uçakların güvenlik sebebiyle acil iniş yapmalarına sebep olmaktadır. Bu tür gerçek ya da sanal tehditler yüzünden yapılan acil inişler ile uçakların kaybedilmesine sebep olan eylemler sonrasında insanlar terörize olmakta, havayolu şirketleri ise ciddi maddi kayıplarla karşı karşıya kalmaktadırlar. Bu sebepten dolayı, başta pilot ve kabin görevlileri olmak üzere hava yolu çalışanlarının ve hava yolu işletmelerindeki güvenlik birimlerinin yapmaları gerekenlerin yer aldığı bir öneri setine ihtiyaç vardır.

\section{Hava Yolu İşletmelerinin Güvenlikleriyle İlgili Öneriler}

Çalışma kapsamında yer alan güvenlik mevzuatının incelenmesi, meydana gelen terör olaylarının içerik analizlerinin yapılması sonrasında hava yolu çalışanlarının dokümanlarına ve şirketlerin güvenlik birimlerine yönelik olarak bir öneri seti hazırlanmıştır.

Buna göre hava yolu çalışanlarının güvenlik dokümanlarında;

- Çalışanların üniformaları, giriş kartları, güvenlik eğitimleri, havalimanı giriş çıkış, apron bölgesinde bulunma usulleri ayrıntı1 bir şekilde yer almalı, standarda bağlanmalı ve bu usul ve standartlara uyum göstermeyenler hakkında uygulanacak idari yaptırımlarla ilgili maddeler hazırlanamalıdır.

- Uçağa yolcuların alımı sırasında kabin ekibi ve yer personelinin nasıl bir "profiling" yapacağı, şüpheli bir durumda ne tür bir hareket tarzı içinde olacağ 1 , hangi birimle iletişim kuracağ 1 ayrıntılı olarak belirtilmelidir.

- "Uçak Güvenlik Araması Çeklisti" teknolojik buluşlara ve gelişmelere göre sürekli güncellenmeli, özellikle kişisel elektronik eşyalar, cep telefonları, tablet ve dizüstü bilgisayarlar, elektronik oyun konsollarına karşı alınacak tedbirlere yer verilmelidir.

- Uçuşta güvenliği tehdit eden Kural Dış1 Yolcu, Uçak Kaçırma, Bomba tehditlerinin yanında siber tehdit, elektronik karıştırma, yerden hava atılacak füze ve silah sistemleri, vb. tehditler hakkında da farkındalık yaratacak maddeler ilave edilmelidir.

- Uçuş öncesi yapılan brifinglere, Uçakta Bomba Hasarıyla ilgili olarak "En Az Risk Bulunduran Bölge (LRBL-Least Risk Bomb Location)"nin yeri hakkında bir madde eklenmelidir. 
- Çalışanların güvenlik yetkinliklerini arttırmak için kurum tarafından çalışanlarla ilgili güvenlik klerans1 uygulamas1 başlatılmalıdır. $\mathrm{Bu}$ uygulamaya ilişkin güvenlik dokümanlarına bölümler eklenmelidir.

- Kaptan pilotun güvenlikle ilgili görev ve sorumlulukları güvenlik sorunu yaratacak kişilere karşı caydırıcı olacak revize edilmeli ve yetkilerini arttıracak yeni maddeler eklenmelidir.

- Meydana gelen güvenlik olaylarının medya etkisini azaltmak amaciyla hava yolu şirketlerinde çalışan personelin bu tür olayları sosyal medyada paylaşmasını engelleyecek maddeler yer almalıdır.

- Uçuş operasyonları sırasında uçağa yönelik olarak yapılacak dron, lazer vb. saldırılarını savuşturmaya yönelik önlemlere yer verilmeli ve bu tür olayların raporlanmasını düzenleyecek başlıklar eklenmelidir.

\section{Hava yolu işletmelerinin güvenlik birimleri ise;}

- Terör örgütlerine karşı ulusal ve uluslararası güvenlik kuruluşlarıyla ve meslek örgütleriyle sürekli bir iletişim içinde olmalıdır,

- Yolcuların uçağa geliş usulleri, taşınacak bagaj ve eşyayla ilgili güvenlik limitleri hassasiyetle (malzeme çeşidi, miktarı, ağırlı̆̆1 gibi bilgileri içerek şekilde) belirlenmelidir.

- Uçuş ekiplerinin ve yolcuların uçağa biniş kartlarının kopyalanma ihtimaline karşı önlem alınmalıdır.

- Tüm şirket personelinin uçuş güvenlik bilinçlerinin en üst seviyede tutulması ve terörist eylemlerin önlenmesi için gerekli eğitim, bilgilendirme ve farkındalık sağlama faaliyetleri arttırılmalıdır.

- Uçuş güvenliğini optimize edecek ve "uçuşta güvenlik ve uçuşta etkinlik" dengesini kuracak bir teknolojik alt tap tesis edilmelidir.
- Şirkette çalışan personele bir güvenlik kleransı uygulaması başlatılmalı ve bu klerans belirli periyotlar halinde yenilenmeli, güvenlik açı̆̆ 1 yaratma potansiyeli olan personelin şirketten uzaklaştırılması sağlanmalıdır.

- Uçuş trafiğginde tehdit olacak yerden atılan füze, lazer, mikrodalga silah sistemlerine karşı tedbir alınmasında sorunlar bulunmaktadir.

- Özellikle güvenlik bakımından sorunlu olan bölgelere olan uçuşlarda İsrail ve ABD'de olduğu gibi “Air Marshall- Hava Güvenlik Personeli” görevlendirilmelidir.

- Ulusal ve uluslararası düzeyde uçuş yapılan bölgelerin güvenlik otoriteleriyle sürekli olarak bilgi alışverişinde bulunulmalı, dron, lazer vb. tehditleri ile siber güvenlik konularına özel bir önem verilmelidir.

- Uçuş eğitimlerinin yapıldığı simülatör tesislerine giriş çıkışlarla ilgili güvenlik tedbirleri bir "simülatör güvenlik dokümanı" ile standart haline getirilmelidir.

Burada sıralanan öneriler çalışma içinde yer alan mevzuat ve örnek olaylarının içerik incelemelerinin aynı zamanda bir uçucu bakış açısıyla yorumlanmasından oluşturulmuştur. Diğer bir ifadeyle burada yer alan öneriler uçuşta güvenlik konusuyla ilgili bizzat yapılan gözlemler sonucu ihtiyaç duyulan konulardır. Bu önerilerin hava yolu şirketlerinde bireysel ve kurumsal düzeylerde dikkate alınarak uygulanmasının uçuş güvenliğini arttıracağı değerlendirilmektedir.

\section{Sonuç ve Değerlendirme}

Havacılık sektöründe meydana gelen hizlı büyüme, aynı zamanda beraberinde güvenlik ve emniyet düşüncelerini beraberinde getirmiştir. Her ne kadar güvenlik konusu operasyon yapılan ülkenin sorumluluğunda olsa da, aynı anda birden fazla ülkede konuşlanmış olan havayolu şirketlerinin varlığı, güvenlik anlayışında ülkeler arası işbirliğini zorunlu hale getirmiştir.

Uçuş emniyet ve uçak güvenliği konuları, havacılık endüstrisinin ekonomik kaygılarına feda edilemeyecek kadar önemli konulardır. Havacılık 
sektöründe yer alan tüm oyuncuların emniyet, güvenlik ve karlılık üçgeni içinde bir denge kurmaları gerekmektedir [55]. Çok fazla kısıtlayıcı emniyet ve güvenlik uygulamaları karlılık oranlarını düşüreceği gibi, sadece kar amacıyla yapılan uçuş operasyonları uçuş güvenliği ve emniyetinde risk oluşturacaktır. Bundan dolayı hava yolu şirketleri, Tokyo Anlaşmasının rehberliğinde hazırlanmış olan mevcut ICAO regülasyonlarına göre uçuş operasyonları yapmak ve kurumsal ve bireysel seviyelerde her türlü güvenlik tehditlerine karşı hazır olmak zorundadırlar.

2018 yılında Uluslararası Sivil Havacilık Örgütü'nün (ICAO) Sözcüsü Anthony Phillip'in yaptı̆̆ı açıklamaya göre; dünayda sınır aşırı seyahat eden 1.4 milyar turist havayolunu tercih etmiştir, ayrıca dünya ticaret hacminin yüzde 35 'i havayolu taşımacılığıyla sağlanmıştır[56]. $\mathrm{Bu}$ durumun sürekli olması için uçakların emniyetli olarak uçurulmasının yanında güvenli bir ortamda da operasyonlarının sağlanması gerekmektedir.

Uçuş güvenliği ve uçuş emniyeti günümüz hava taşımacılığının en önemli konusu olarak karşımıza çıkmaktadır. Bir hava yolu şirketi yolcuları tarafindan ne kadar beğenilirse beğenilsin, güvenlik zafiyeti sebebiyle yaşanacak bir terör saldırısı yüzünden telafisi zor yapılacak zararlarla karşı karşıya kalabilecektir. Yukarıdaki örnek terör olaylarında da bahsedildiği gibi, 2016 yılında Atatürk Havalimanında yapılan saldırı ve sonrasinda meydana gelen 15 Temmuz darbe girişimi Türk sivil havacılığında yaklaşık 2 yıllık bir gerileme yaşanmasına, hava yolu şirketlerinin büyümelerinin bu 2 y1l boyunca ertelenmesine sebep olmuştur. Benzer bir şekilde Brüksel havalimanina yine 2016 yılında yapılan terör saldırısı sonrasında havalimanının belirli bir süre toptan kapatılmasına sebep olmuş ve maddi manevi bir kayıp yaşanmıştır.

Burada sıralanan gerçeklerden yola çıkarak hazırlanan bu çalışmada, öncelikle yöntem olarak nitel araştırma tekniklerinden arşiv tarama ile mevcut güvenlik mevzuatı ve örnek terör olaylarından elde edilen veriler belirlenmiştir. Devamında ise örnek olaylarla belirlenen verilerle ilgili bir içerik analizi yapılarak birtakım bulgulara ulaşılmıştır. Bulguların, uçuculuk mesleğini icra eden bir pilot olmanın da avantajından yararlanılarak uçuş operasyonlarının doğasına uygun bir şekilde değerlendirilmesi yapılmıştır. Sonrasında ise bir hava yolu işletmesinde çalışanların güvenlik dokümanlarına ithal edilmek üzere bir öneri seti hazırlanmış, bu öneri seti içine aynı zamanda kurumsal anlamda yapılacaklar listesi de ilave edilmiştir.

Hazırlanan öneri setinde özet olarak;

- Çalışanların güvenlik dokümanları; uçuş güvenliğini tehdit edecek risklere karşı revize edilmeli, bu kapsamda, bireysel standardizasyona önem verilmeli, kaptan pilotların güvenlik konusundaki yetkileri arttırılmalı, sosyal medya, dron, lazer ve teknolojik gelişmeler bağlı olarak geliştirilen tehditlere karşı önlem alınmalı ve uçuş güvenliği ile ilgili tüm konular uçuş öncesi brifinglerde işlenmelidir.

- Kurumsal olarak ise; şirketlerin güvenlik birimleri, her türlü tehdide karşı ulusal ve uluslararası ilgili kurumlarla iletişim içinde olmalı, şirket personelinin uçuş güvenlik bilinçlerinin arttırılması için gerekli eğitim, bilgilendirme ve farkındalık sağlama faaliyetlerini arttırmalı, "uçuşta güvenlik ve uçuşta etkinlik" dengesini kurmalıdır. Ayrıca, ihtiyaca bağlı olarak Türkiye'de olmayan ancak İsrail ve ABD'de uygulanan "Air Marshall- Hava Güvenlik Personeli" uygulaması düşünülmelidir.

Sonuç olarak, yola çıkarak hava yolu şirketinde yer alan yöneticiler ve çalışanların, uçuş ve uçak güvenliği hakkında tam bilgili ve duyarlı olmaları ve kendilerini sürekli olarak güvenlik konusunda güncel tutmaları önemlidir. Aksi halde yapısı gereği güvenlik bakımından oldukça kırılgan olan hava yolu taşımacılığının gelişmesi mümkün değildir. Çünkü uçak güvenliği olmayan yerde yolcu da kargo da olmaz ve hava yolu taşımacılı̆̆ından da bahsedilemez.

\section{Etik Kurul Onayı}

Gerekli değil 


\section{Kaynaklar:}

[1] International Civil Aviation Organization (ICAO), Part I, International Standards and Recommended Practices (SARP), "International Commercial Air Transport Aeroplanes”, 11th edition ICAO, 2018.

[2] International Civil Aviation Organization (ICAO), "Secretariat Study on the Safety and Security Aspects of Economic Liberalization", European Council Publication, 2005.

[3] International Civil Aviation Organization (ICAO), "SECURITY, Safeguarding International Civil Aviation Against Acts of Unlawful Interference"International Standards and Recommended Practices (SARP), Annex 17, , 9th edition ICAO, 2011.

[4] European Commmision, EC 300-2008, "Mobility and Transportation, Air Travel, Security", https://ec.europa.eu/transport /modes/ air/security/legislation_en. [Erişim Tarihi: 03.06.2020]

[5] Sivil Havacılık Genel Müdürlüğü, (SHGM), "Havacılık İşletmeleri Güvenlik Yönetmeliği ve Organizasyonu", Sivil Havacılık Talimatı STH-17. -3, 2010.

[6] T. Şahan, "Havacılık Güvenliğii”, Sivil Hava Ulaştırma İşletmeciliği Ön Lisans Programı, Ders Notları, İstanbul Üniversitesi Açık Ve Uzaktan Eğitim Fakültesi 2020.

[7] Hatice Başkale, "Nitel Araştırmalarda Geçerlik, Güvenirlik ve Örneklem Büyüklüğünün Belirlenmesi”, Dokuz Eylül Üniversitesi Hemşirelik Fakültesi Elektronik Dergisi , 9(1), 23-28, 2016.

[8] Creswell, J. W. "Qualitative Enquiry And Research Design: Choosing Among Five Approaches". California: Sage, 2007.

[9] Denzin, N. K. "The Research Act: A Theoretical Introduction To Sociological Methods", New York: McGraw-Hill, 1978.

[10] Krefting, L. "Rigor In Qualitative Research: The Assessment Of Trustworthiness", The
American Journal of Occupational Therapy, 45 (3), 214-222, 1991.

[11] Creswell, J.W. "Nitel araştırma yöntemleri", (Çev: Dr. S.B. Demir ve M. Bütün), Ankara: Siyasal Kitabevi, 2014

[12] E. Gerede "Havacılık Emniyeti Ve Havac1lı Güvenliği Kavramları Arasındaki İlişki Ve Farkların Belirlenmesine Yönelik Bir Araştırma", Anadolu Üniversitesi, Sivil Havacılık Yüksekokulu, Yönetim, Y11: 17, Say1: 54, Haziran 2006.

[13] Statista, "Number Of Flights Performed By The Global Airline Industry From 2004 To 2020,"

https://www.statista.com/statistics/564769/ai rline-industry-number-of-flights/ [Erişim Tarihi: 27.04.2020]

[14] Temizel, M. "Terörizmde Yeni Milad: 11 Eylül 2001", Selçuk Üniversitesi Sosyal Bilimler Meslek Yüksekokulu Dergisi , 14 (1-2), 311-348, 2014.

[15] Qatar Airlines Publication, "Guidance Material Submission of Airline Operator Security Programme for Qatar Operations" Appendix A, Edition: 01 Revision: 00, Doha, 2016.

[16] Qatar Airlines, QCCA, "Guidance Material, Submission of Airline Operator Security Programme for Qatar Operations", Doha, 2016

[17] Qatar Airlines Publication, "Notes on Aircraft Security Search Checklist Form", 2018.

[18] Sivil Havacılık Genel Müdürlüğü (SHGM) "Havacılık Güvenliği Sistemi", Havacılık Güvenliği Daire Başkanlığı, Birinci Baskı, Yayin No : HGD / G-1, Nisan 2010.

[19] European Commission MEMO-15-61152015, "European Agenda on Security - State of Play", November 17, 2015. http://europa.eu/ rapid/pressrelease_MEMO-15-6115_en.htm. [Erişim Tarihi: 20.03.2020]

[20] AtlasGlobal Hava Yollar1, "Operation Manual- Part A", 2018 
[21] Devlet Hava Meydanları İşletmesi (DHMI) Genel Müdürlüğü Havacılık Acil Yardım Ve Güvenlik Dairesi Başkanlığı "Havacılık Güvenliği Eğitmen El Kitabı", https://www.dhmi.gov.tr/Lists/

DosyaYonetimiList /Attachments/ 270/Havacilik Guvenligi Egitmen ElKitabi.pdf. [Erişim Tarihi: 01 Haziran 2020]

[22] ICAO 1944 Agreement, "Convention on International Civil Aviation" -, Doc 7300, https://www.icao.int/publications/pages/doc 7300.aspx. [Erişim Tarihi: 07 Nisan 2020]

[23] SHGM, 2018 Y1l Duyurular, "Tokyo Sözleşmesi Tadilatı Cumhurbaşkanımız tarafindan onaylandı", http://web.shgm.gov.tr/tr/mansethaber/5914-tokyo-sozlesmesi-tadilaticumhurbaskanimiz-tarafindan-onaylandi [Erişim Tarihi: 27.04.2020].

[24] Aerotime News, December, 3, 2015 "More than $50 \mathrm{EU}$ airports deploy Itemiser 4DX explosives trace detectors," http://www.aerotime.aero/en/airports/airport s-news/other/20608-more-than-50-euairports-deploy-itemiser-4dx-explosivestrace-detectors [Erişim Tarihi: 17.01.2020].

[25] B. Hoffman, Inside Terrorism, New York, USA, Columbia University Press. 2006.

[26] E. Azani, L. Lvovsky, D. Haberfeld, "Trends in Aviation Terrorism", International Institute for Counter Terrorism, UN, New York, 2016.

[27] W. Stewart, Evening Standard News, November 23, 2015 "Russian plane crash: Bomb on tourist jet that crashed in Egypt 'was placed under a seat", , http://www.standard. co.uk /news/world/bomb-on-russian-touristjet-that-crashed-in-egypt-was-placedunder-a-seat-a3120741.html. [Erişim Tarihi: 07.01.2020].

[28] A.Jamieson, NBC News March 22, 2016, "Mother of Satan' Explosive Likely Used in Attack:

Expert",http://www.nbcnews.com/card/mot her-satan-explosive-likely-used-attackexpert-n543441. [Erişim Tarihi: 15.01.2020].
[29] I. Bloomenthal, R. Rimerman, I. Eichner, R. Case, A. Shomplevi, A. Kotelratz, Ynet News June 29, 2016 , "Flights Renewed in Istanbul. Israelis at the airport: It is chaos, we are exhausted", http://www.ynet.co.il/ articles/ 0,7340,L-4821867,00.html. [Erişim Tarihi: 16.01.2020].

[30] B. Davies, "Terrorism, Inside a World's Phenomenon, New York, USA, Virgin Books, 2005.

[31] Site Intelligence Group, April 21, 2016, "Security Fail: Cologne Airport's Terrorism Emergency Evacuation Plan Accidently Put On Internet",. https://www.rt.com/news/340484-germanyterrorism-cologne-airport/. [Erişim Tarihi: 16.01.2020].

[32] M. Townsend, P. Beaumont, The Guardian November 8, 2015, "Russian plane crash: Calls for new era of airport security after Sinai terror", https://www.theguardian.com/world /2015/nov/07/new-era-airport-security-sinaiterror. [Erişim Tarihi: 14.01.2020].

[33] P. Graff, Reuters News January 29, 2016, "Exclusive: Egypt Air Mechanic Suspected In Russian Plane Crash" http://www.reuters.com /article/us-egyptcrash-suspects-idUSKCN0V 712V?Utm _source=twitter. [Erişim Tarihi: 14.02.2020].

[34] M.Walsh, Daily News. September 3, 2014, ISIS Terrorist From Minnesota Worked At Major American Airport: Report, http://www.nydaily news. com/news/world/isis-terrorist-minneapolisworked-major-american-airport-reportarticle-1.1925924, [Erişim Tarihi: 13.03.2020].

[35] T.Lyden, Fox 9. November 2016, "INSIDER THREAT: Side-by-side with a future terrorist at MSP Airport", 2014. Retrieved from: http://www.fox9.com/fox-9-mn-specialarchive/1642467-story. [Erişim Tarihi: 11.03.2020]

[36] J.Hayward, Breitbat. November 10, 2015, "Worries about Airport Security after Possible ISIS 'Inside Job' in Egypt", http://www.breitbart. com/nationalsecurity/2015/11/10/u-s-worries-airport- 
security-possible-isis-inside-job-egypt/.

[Erişim Tarihi: 12.03.2020].

[37] J.Robinson, Dailymail. April 21, 2016, "ISIS bomb maker 'worked at Brussels Airport for FIVE YEARS' before launching suicide attack as it emerges hidden prayer room was found at terminal 'where radicalised staff prayed in secret" http://www.dailymail.co.uk/news/article3551669/ ISIS-bomb-maker-workedBrussels-Airport-FIVE-YEARS-launchingsuicide-attack-emerges-hidden-prayer-roomterminal-radicalised-staff-prayedsecret.html. [Erişim Tarihi: 12.03.2020].

[38] J.Jankowski, Planet Free Will. March 25, 2016, "Top Jihadist Claims ISIS Has Agents Working in Western Airports, Metro Stations",

http://planetfreewill.com/2016/03/25/topjihadi-claims-isis-agents-working-westernairports/. [Erişim Tarihi: 12.03.2020].

[39] ICT JWMG Desk, 2015, "Recent Jihadi Discourse Pertaining to Aviation Threats", https://www.ict.org.il/Article/1508/RecentJihadi-Discourse-Pertaining-to-Aviation. [Erişim Tarihi: 11.03.2020].

[40] The Guardian December 27, 2015 "Kurdish PKK rebels claim responsibility for deadly Istanbul airport blast", http:/www.theguardian. com/ world/2015/dec/27/kurdish-rebels-claimresponsiblity -for-deadly-istanbul-airportblast. [Erişim Tarihi: 11.03.2020].

[41] Israel Defense News, August 31, 2014, "The System that prevented the Closure of Ben Gurion Airport", http://bit.ly/2aRHiru, [Erişim Tarihi: 10.03.2020].

[42] Israeli Ministry of Transport, "Serious Incident Case no. 88-15 - Aviation Incidents and Accidents Investigation. Information about security incident," http://aiai.mot.gov.il/ publicationcbl/hodahot-cll/1236-1099. [Erişim Tarihi: 11.03.2020].

[43] A.Ashkenazi, Walla News. August 12, 2015, "Drone Passes a Plane Planning to Land at Ben-Gurion Airport, Nearly Causing a Tragedy" http://news.walla.co.il/item/2881221.

[Erişim Tarihi: 11.03.2020].

[44] [44] Israeli Intel Center, "Analyst Notes: Terrorist Eyes in the Sky", Tel Aviv, Israel, Defence Pubs, 2016.

[45] FAA Publication, "Unmanned Aircraft Systems (UAS) Registration in Federal Aviation Administration", https:/www.faa.gov/ uas/registration. [Erişim Tarihi: 11.03.2020].

[46] European Cockpit Association- ECA, "Piloting Safety UAS+- Unmanned Aircraft Systems", 2017, https://www.eurocockpit. be/expertise/uas?page $=3$. [Erişim Tarihi: 01.06. 2020]

[47] Sivil Havacılık Genel Müdürlüğü (SHGM) “ İnsansiz Hava Arac1 Sistemleri”, Sivil Havacılık Talimatı (SHT-İHA), 2016.

[48] International Virtual Aviation Organization (IVAO), "A multiplayer simulator operates as a free social network with tens of thousands of users, including an Israeli community that teaches the work method in Israel", 2016, http://ivao.org.il. [Erişim Tarihi: 10.03.2020].

[49] R. Kais, Ynet News, December 12, 2015, "Report: ISIS training fighters to fly commercial aircraft in Libya", http://www.ynetnews. com/articles/0,7340,L-4733894,00.html. [Erişim Tarihi: 10.03.2020].

[50] FBI Publication, "FBI Simulation Regarding The Dangers Of Laser Pointers Aimed At Airplanes" November 11, 2014, https://www.fbi.gov/news/stories/2014/febru ary/protecting-aircraft-from-lasers. [Erişim Tarihi: 12.03.2020].

[51] ABC News, July 16, 2015, "Pilot Has Blurred Vision After Planes Are Struck by Lasers Near Newark Airport", http://abcnews.go.com/US/11-planes-strucklasers-approaching-newarkairport/story?id=32488609. [Erişim Tarihi: 21.03.2020].

[52] InfoSec Institute, "Cyber Threats against the Aviation Industry",2014. http://resources. 
infosecinstitute.com/cyber-threats-aviationindustry/ . [Erişim Tarihi: 21.03.2020].

[53] I. Curiel, Ynet. March 23, 2016, “ Shin Bet Revealed: Jihadist Breached IDF Drone Systems."

http://www.ynet.co.il/articles/0,7340,L4782233,00.html. [Erişim Tarihi: 22.03.2020].

[54] European Commission Report, "Commission presents a new Aviation Strategy for Europe", December 7, 2015. Retrieved from: http://europa.eu/rapid/pressrelease_IP-15-6144_en.htm. [Erişim Tarihi: 23.03.2020].
[55] M.M. Başdemir, "Tüm Havacılar İçin Ekip Kaynak Yönetimi”, İstanbul, Türkiye, Beta Yayınevi, 2020.

[56] Turizm Günlüğü 2019, “2018 Y111 Uuslararası Havayolu Trafiği Rakamları Açıklandı", https://www.turizmgunlugu .com/2019 /01/10/2018-yili-uluslararasihavayolu-trafigi-rakamlari-aciklandi/. [Erişim Tarihi: 22.04.2020]. 